\title{
Lunar alignments at Ur: Entanglements with the Moon God Nanna
}

\section{William F. Romain}

Independent Scholar

romainwf@aol.com

\begin{abstract}
In ancient Sumer the Moon god, Nanna, was the patron deity for the city of Ur. In this article data are presented showing how the city of Ur was astronomically aligned to the Moon. Assessments are made using satellite imagery in combination with early maps and aerial photographs. Also shown is how the geographic location of Ur relative to Nippur may be related to the Moon's 18.6-year nodal cycle. It is also shown how lunar calendric data are likely embedded in an ancient legend that tells of the Moon god's journey from Ur to Nippur. Together these and other lines of evidence demonstrate how one of the world's oldest cities was shaped through its entanglement with the gods - and in particular, the Moon god Nanna.
\end{abstract}

Keywords: Sumer; Ur; ziggurat; Nanna; Ur-Nammu

\section{Introduction}

The distinguished Assyriologist and scholar of Sumerian history Samuel Kramer $(1956,1)$ famously proclaimed that "History Begins at Sumer". That might have been an overstatement, but it is true that Sumer was one of humanity's cradles of civilisation and that the Sumerian city of Ur is therefore of special significance to the understanding of world history. This includes the detail that the city itself - and not just its Great Ziggurat - was aligned intentionally to the Moon. The alignment of the Great Ziggurat to the Moon's maximum north rise has been noted by a number of investigators (e.g. González-García 2015; Nadali and Polcaro 2016; Sparavigna 2016; Tiede 2011, 2018). To my knowledge, however, it has not previously been recognised that the entire city is lunar-aligned. This paper shows how this is so, based on analyses of pre-restoration aerial photographs in combination with Google Earth imagery. It also shows how the geographic location of Ur relative to the city of Nippur may have had lunar significance. Lending support to the intentionality of the above findings are astronomic assessments of two Sumerian stories known as the Journey of Nanna to Nippur and Shulgi's Run. 


\section{Background}

The focus of this paper is Ur during the Third Dynasty (c. 2100-2000 BC), also known as Ur III. This was the height of the Sumerian empire, when Ur was one of the largest and most powerful city-states in the world. Today Ur is in ruins, except for foundation remnants and its multi-tiered ziggurat, which has been partially restored.

Geographic coordinates for Ur (from the centre of the Great Ziggurat) are $30^{\circ} 57^{\prime} 45.9^{\prime \prime} \mathrm{N}$ $46^{\circ} 06^{\prime} 11.4^{\prime \prime} \mathrm{E}$, in modern-day Iraq. The site is located about $220 \mathrm{~km}$ southeast of Babylon (Figure 1). Ur occupies a low hill, or tell. During Sumerian times, Ur was situated on the banks of the Euphrates River and near the Persian Gulf. This positioned Ur at an important crossroads for trade and commerce. However, over the course of thousands of years, the Euphrates River changed its course away from Ur, eventually leading to the city's demise. Today, the closest approach of the Euphrates River to Ur is about $10 \mathrm{~km}$ to the northeast. So too, the Persian Gulf has receded and its present coastline is about $230 \mathrm{~km}$ southeast of Ur. The ruins of the Great Ziggurat were identified in the nineteenth century, and most of what is known about the site is even now still based on excavations that were undertaken by C. Leonard Woolley between 1922 and 1934 (Woolley and Moorey 1982, 13). The ruins show that Ur, like its contemporaries, was a walled city (Figure 2), and findings within the city include multiple temples, at least one palace, residential structures and cemeteries. Over the course of its history, Ur was destroyed and rebuilt multiple times; the earliest levels date to c. 3800 BC (Woolley 1955b), and these yielded pot sherds, flint, obsidian artefacts and clay figurines. The famous Royal Cemetery and treasures found in

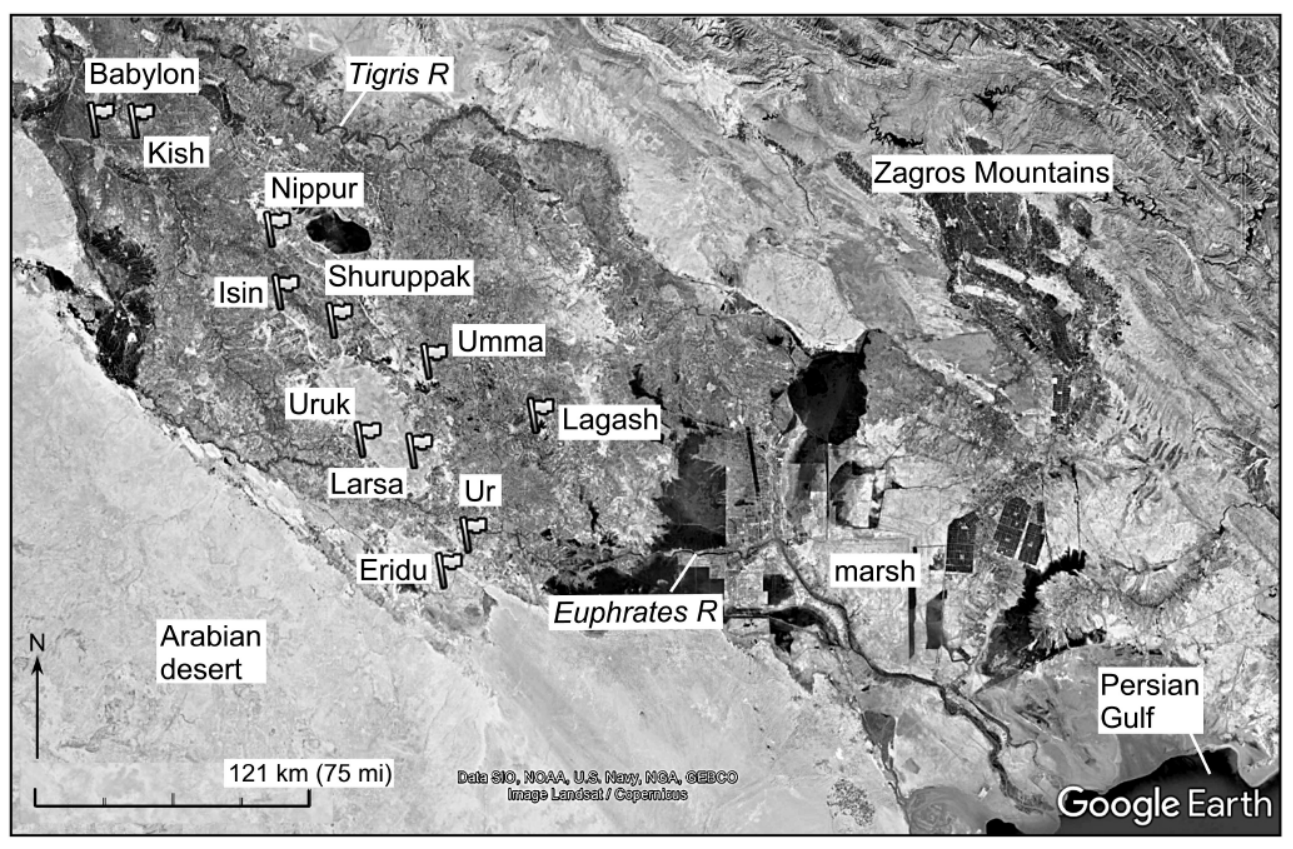

FIGURE 1. Google Earth view of southern Mesopotamia, showing locations of selected Sumerian cities (annotation by author). 


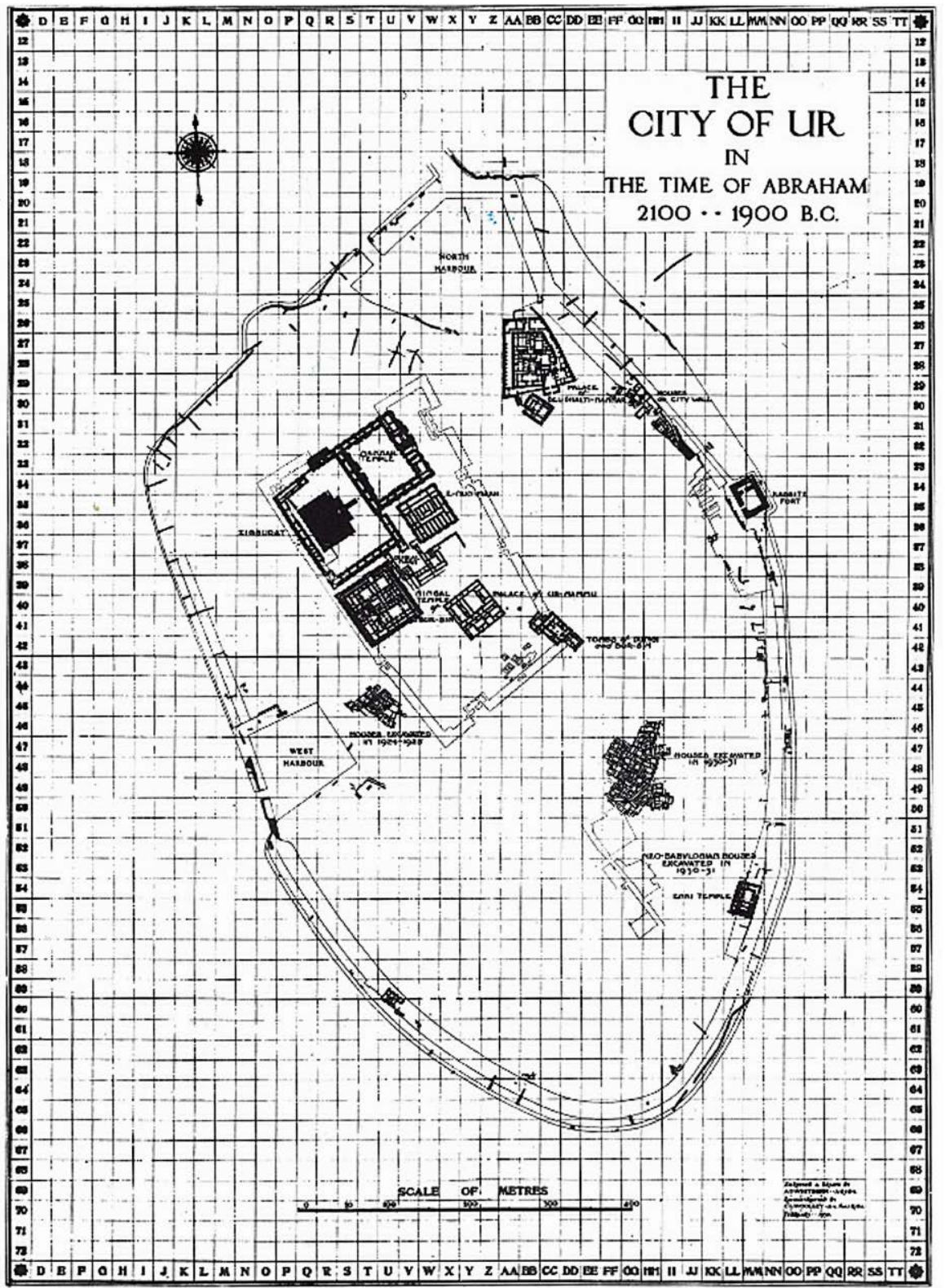

FIGURE 2. Plan of the city of Ur (from Woolley 1974, pl. 61).

the so-called Great Death Pit (Zettler and Horne 1998) are associated with the city's Early Dynastic period (c. 2900-2350 BC).

Around 2350 BC Akkadians led by Sargon the Great conquered Sumer, and for the next two hundred years the region was ruled by Akkadian kings. By this time, Mesopotamian city-states each had their own patron deity, with a main temple dedicated to that god. For example, Enlil, the god of air, wind and storms was the patron god of Nippur; 
Inanna, the goddess of love and war was the chief goddess at Uruk; Enki, the god of magic and fresh water was the god of Eridu; and Utu, the Sun god, was the patron deity at Larsa and Sippar (Zettler 1998, 5). At Ur, the patron deity was the Nanna, the Moon god.

The Third Dynasty was a brief period of a century, during which Sumerian rule re-asserted itself. This was the high point of Sumerian civilisation. Following a series of successful military campaigns, the governor of the city, Ur-Nammu, declared himself king. Between c. 2112 and 2095 BC Ur-Nammu expanded his rule to more than two dozen city-states and united Sumer as an empire. Among Ur-Nammu's many accomplishments is that he began construction of the Great Ziggurat and other major buildings at Ur.

Ur-Nammu's reign lasted 18 years. He was succeeded by his son, Shulgi. Shulgi's reign lasted 42 years, during which he expanded the Sumerian empire and completed the ziggurat and other projects his father had started. Three more Sumerian kings followed Shulgi: Amar-Sin, Shu-Sin and Ibbi-Sin. Figure 3 shows the layout of Third Dynasty structures at Ur.

The Third Dynasty came to an end in 2004 BC when Ur was sacked by the Elamites from the area of modern-day Iran and Gutians from the Zagros Mountains to the east. Following the fall of the Third Dynasty and over the next fifteen hundred years, Ur was conquered or otherwise fell under the control of various powers including Hammurabi of Babylon, the Hittites, Kassites, Assyrians, Chaldeans and Persians. The city was sacked, damaged and rebuilt several times. Among the rulers who rebuilt and repaired city structures were Kurigalsu I, Sinbalatsu-iqbi, Nebuchadnezzar II, Nabonidus and Cyrus II of Persia. Of these rulers, it was Nabonidus, the last king of the Neo-Babylonian Empire who ruled between C. 556 and 539 BC, who made the most significant changes to Ur. Nabonidus was a devotee of the Moon god and undertook great efforts to restore Ur to its former glory. He restored the ziggurat, and according to Woolley (Woolley and Moorey 1982, 235) may have added levels to the structure. Further, Nabonidus expanded the temple structures south of the ziggurat.

The final chapter for Ur was written in the sixth century BC when King Cyrus II of the Persian Empire conquered Babylon, bringing Ur into his domain. Cyrus ordered some repair and restoration work to the city. Unfortunately for Ur, however, climate conditions were changing and the end for the city came as a combined result of drought, the changing course of the Euphrates River and the recession of the Persian Gulf. By 500 BC the city was no longer populated and desert sands covered it for the next 1500 years.

It is important to note that even though the buildings at Ur were often damaged and sometimes levelled by invading armies, the original foundations of Ur III buildings survived. This allowed the re-building of structures following their original footprints. As Woolley (1965, 140-141) explains:

Of the temples erected by Ur-Nammu and his descendants some survive to the present day; others were rebuilt by later kings, but in that case the ground-plan of the original was so faithfully followed - often indeed the foundations were the same - that the new work may be taken as a replica of the old and can be used indifferently to complete the picture. 


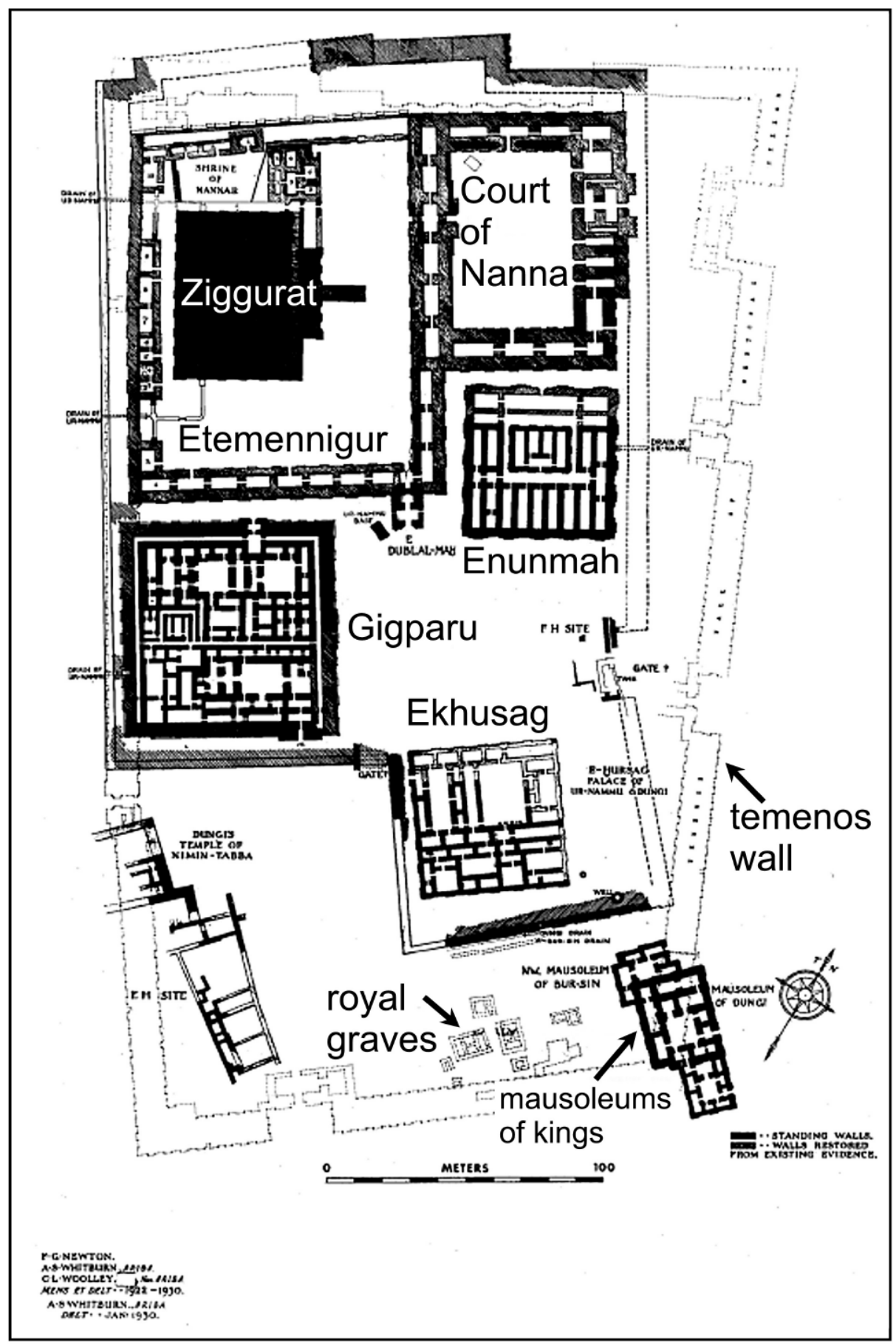

FIGURE 3. Plan of Ur showing structures inside the temenos area during the Ur III (from Woolley 1974, pl. 5, annotation by author). 
What this means for the present assessment is that while buildings may have been repaired or rebuilt, the orientation of the ziggurat and entire city as built during the Third Dynasty can be evaluated using aerial photographs of extant remains. Also useful is that the founders of Ur III structures were often identified by stampings on bricks used in the construction (Woolley 1955a, 123).

\section{The Moon God}

According to Kramer $(1956,87)$, "[t]he Sumerians of the third millennium BC had hundreds of deities, at least by name." Among the most important of the gods was the Moon god. This male deity was known by the Akkadians as Suen or Sin and by the Sumerians as Nanna (Black and Green 1992, 135; Collon 1992, 19). Accounts based in fragmentary texts sometimes differ regarding who begat whom; it is generally agreed, however, that Nanna was the son of Enlil and Ninlil and that Nanna's wife was Ningal, also known as the "Goddess of Reeds". The children of Nanna and Ningal were Utu, the male Sun god and Inanna, goddess of fertility, who was manifested in visible form as the planet Venus (Saggs 1988, 259-260).

Identification of the Moon god is most often made where he is associated with a crescent (Collon 1992, 20; Stol 1992, 245). An exceptionally detailed anthropomorphic representation of the Moon god dating to Neo-Assyrian times is shown in Figure 4. Additionally, the Moon was sometimes symbolised as a boat (see later discussion). And often times, especially in hymns, the Moon god was referred to as a bull (see e.g. Woolley and Moorey 1982, 140), an association suggested by the bull's recumbent crescent-shaped horns.

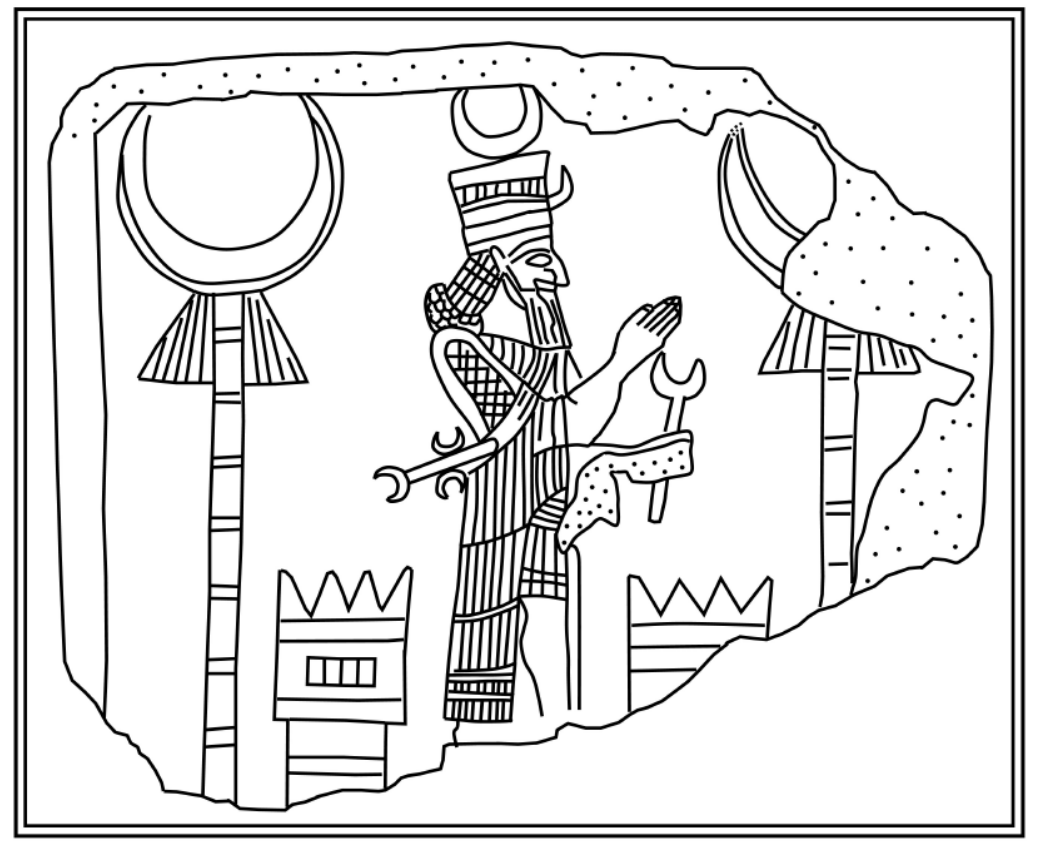

FIGURE 4. Drawing by author of Neo-Assyrian image of Moon god based on photograph of stele from Til Barsp. Aleppo National Museum, inventory \# 4526 (see also Colbow 1997, fig. 16). 
As Moon god, Nanna was lord of the night, the month and the lunar calendar. Nanna was also the "lord of wisdom", and an underworld judge. In his Akkadian manifestations, Leick (1991, 152 - author's transliterations) explains:

He was seen as a horned bull (qarnu), a 'fruit that grows by itself' (enbu ša ina ramanišu ibbanu) a reference to the old belief that the Moon generates itself after each waning), the one "who promotes abundance to the crops" (nadin hegalli ana mašre), who regulates time, is wise, decides the Fates, and is merciful. Sin was an important oracle god and also a healer.

\section{Methods}

To determine how close a prehistoric structure is aligned to a celestial event several pieces of information are needed. First is the azimuth of the targeted celestial body (in this case the rising and settings azimuths for lunar standstill events) - where azimuth refers to the horizontal angle measured clockwise in degrees from north. Second is the orientation of the structure relative to true north. The closer the two azimuths are to each other, the closer the alignment. For the present assessment lunar standstill events were calculated for 2000 BC using standard formulae (see, for example, McCormac 1991, 345; see also Romain 2017, 171-172; 2018a, 306; 2018b, S2-S3).

Lunar declination values for the year 2000 BC were determined from Ruggles (1999), cross-checked against Aveni (2001). Even if structures at Ur were built hundreds of years before or after 2000 BC, the change in the Moon's apparent position due to changes in the obliquity of the orbit happens so slowly and is so small in the short term that the resulting differences in rising and setting azimuths would not be noticeable to the naked eye. A horizon elevation of $0.0^{\circ}$ was used. This value was derived from a computergenerated view of the horizon from the base of the ziggurat using the online application HeyWhatsThat (Kosowsky 2012). This entering value was then corrected for refraction $\left(-0.5^{\circ}\right)$, lower limb tangency $\left(+0.25^{\circ}\right)$ and lunar parallax $\left(+0.95^{\circ}\right)$. The resulting lunar maximum north rise azimuth for $2000 \mathrm{BC}$ is $56.0^{\circ}$.

The next step was to assess the orientation of Ur. Unfortunately, Woolley's maps are not helpful in this regard. Comparison of Woolley's maps to extant Ur structures identified in Google Earth imagery reveals that although his plans showing the dimensions of walls and major structures are accurate, the north arrows on his large-scale maps (Woolley 1939 , pls. 84,$87 ; 1974$, pl. 53 ) are in error by $2.5^{\circ}-3.0^{\circ}$. This is equivalent to about five or six Moon diameters.

According to notations on the drawings, Woolley's (1939, pl. 84) plan of the Great Ziggurat is credited to M. V. Duffell, while his plan of the temenos (Woolley 1974, pl. 53) credits several persons in addition to himself. Given that multiple persons worked on these drawings, I suspect that the correction to convert magnetic azimuths as recorded in the field to true north was inadvertently applied twice, thereby resulting in the peculiar skew of posited true north arrows. (As per the NOAA online magnetic field calculator, the magnetic declination at Ur in 1929 was $2.76^{\circ}$ east - National Oceanic and Atmospheric Administration n.d.). Occasionally one sees Heinrich (1982) cited as a map source for Ur. 
Heinrich produced artistically impressive plans for many Mesopotamian sites; unfortunately, however, his representations of Ur appear to have been based on Woolley's plan and replicate Woolley's incorrect north arrows (cf. Woolley 1939, pl. 84; Heinrich 1982, Abb. 223). Without an accurate site plan reliably tied to true north, the next-best alternative for assessing the orientation of Ur was to use two aerial photographs of the site taken in 1927 and 1930. The photographs were taken by the 84th Squadron of the British Royal Air Force (RAF) (Woolley 1934, pl. 2 caption), which undertook numerous reconnaissance missions from its base in Baghdad between World Wars I and II. Like Woolley's maps, these photos were compared with Google Earth imagery. Although the site was mostly abandoned after Woolley's excavations, so that most of it is today obscured due to in-fill by windswept sand, Google Earth does show the Great Ziggurat (which was partially restored in the 1980s) and part of the Enunmah building (discussed below). Using these structures it was possible to orient the old aerial photographs to true north. Once that was accomplished the historic photos were assessed for possible astronomic alignments. The procedure as applied to the 1927 photo was as follows.

As shown by Figure 3, the Enunmah building is situated just south of the Court of Nanna. According to Woolley $(1974,45)$, "with the single exception of the Ziggurat, E-nun-mah has the longest and the most consistent history. [...] Ur-Nammu was responsible for the temple in its existing form; he built it in mud brick". He continues that, during the course of its long history the Enunmah building was "overthrown" and destroyed and repeatedly rebuilt. But importantly and with specific reference to his plan of the Enunmah shown here in Figure 5a, he explains (Woolley 1974, pl. 58), the "walls of all periods follow virtually the same lines". Woolley's other illustrations showing the structure at various stages throughout Ur's history support that assertion.

In Figure 5a dotted line arrows identify the walls used to align the 1927 aerial photograph. Figure 5b shows a recent Google Earth image that includes the walls shown in Figure 5a. I chose these particular walls for the rectification procedure because they are quite visible in both historic and modern aerial imagery and, as mentioned, they have remained intact since their construction. Using the Google Earth ruler tool the azimuths for the two walls shown in the Google Earth image were measured and found to be $56^{\circ}$ and $146^{\circ}$, respectively.

With azimuths for these walls duly noted, the 1927 aerial photograph was rotated so that the azimuths for the walls in the photograph matched those in the Google Earth image. Figure $5 c$ shows an enlarged detail of the result. Since the Google Earth ruler tool uses true north for its reference (as can be confirmed by turning on the Google Earth grid lines tool showing lines of longitude), it follows that the 1927 aerial photo is now oriented to true north. With the 1927 aerial photo correctly oriented and knowing the calculated lunar azimuths, the layout of the city and its main structures were assessed for lunar alignments.

The Google Earth application provides a function that sets the tilt and compass to zero once a target is centred (View $\rightarrow$ Reset $\rightarrow$ Tilt and Compass). Applying this tool and comparing azimuth values between modern Google imagery for Ur and the 1927 and 1930 aerial photos suggests that the old aerial photos were taken from positions as near to vertical as can be discerned at map scale. 


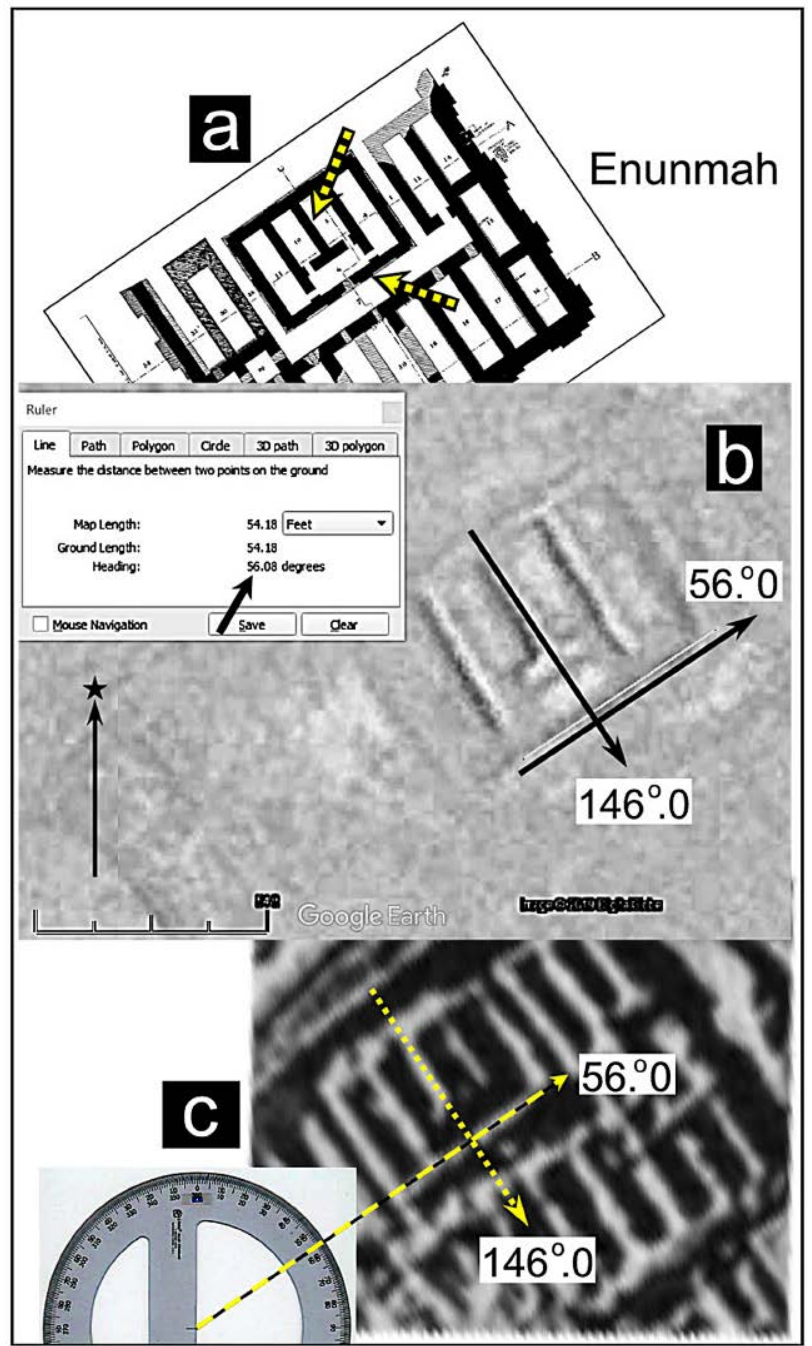

FIGURE 5. (a) Woolley's plan of the Enunmah building (from Woolley 1974, pl. 58), dotted line arrows show the walls to be measured (annotation by author); (b) Google Earth image showing computer-measured azimuths of selected walls in the Enunmah building (annotation by author); (c) enlarged detail of the 1927 aerial photo, oriented so that wall azimuths are coincident with those in Google Earth image (photograph by British Royal Air Force, from British Museum Quarterly 1, pl. XLIVa - annotation by author).

When working with Google Earth imagery it is useful to have an understanding of the application's accuracy limits. As Pulighe and colleagues note: "the accuracy of the images is heavily dependent upon the accuracy of the orientation data plus the quality of the DEM [Digital Elevation Model] used" (Pulighe et al. 2015, 17; see also Potere 2008). Fortunately, the ground-based survey of Nadali and Polcaro (2016) confirms the $56^{\circ}$ azimuth of the ziggurat - which, as discussed below, corresponds to the minor axis for the entire city. 


\section{Results}

As mentioned, several researchers have previously noted that the ziggurat is aligned along its minor axis to the Moon's maximum north rise. Specifically, the ziggurat faces that lunar event. To the best of my knowledge what has not been noted in the literature is that the entire city is likewise oriented to the Moon. Figure 6 shows the Moon's maximum north rise azimuth relative to the southeast to northwest axis of the city. As indicated, this longitudinal axis of $326.0^{\circ}$ is orthogonal to the lunar azimuth of $56.0^{\circ}$. Detailed assessments for the structures that establish the lunar alignment and its orthogonal are provided below.

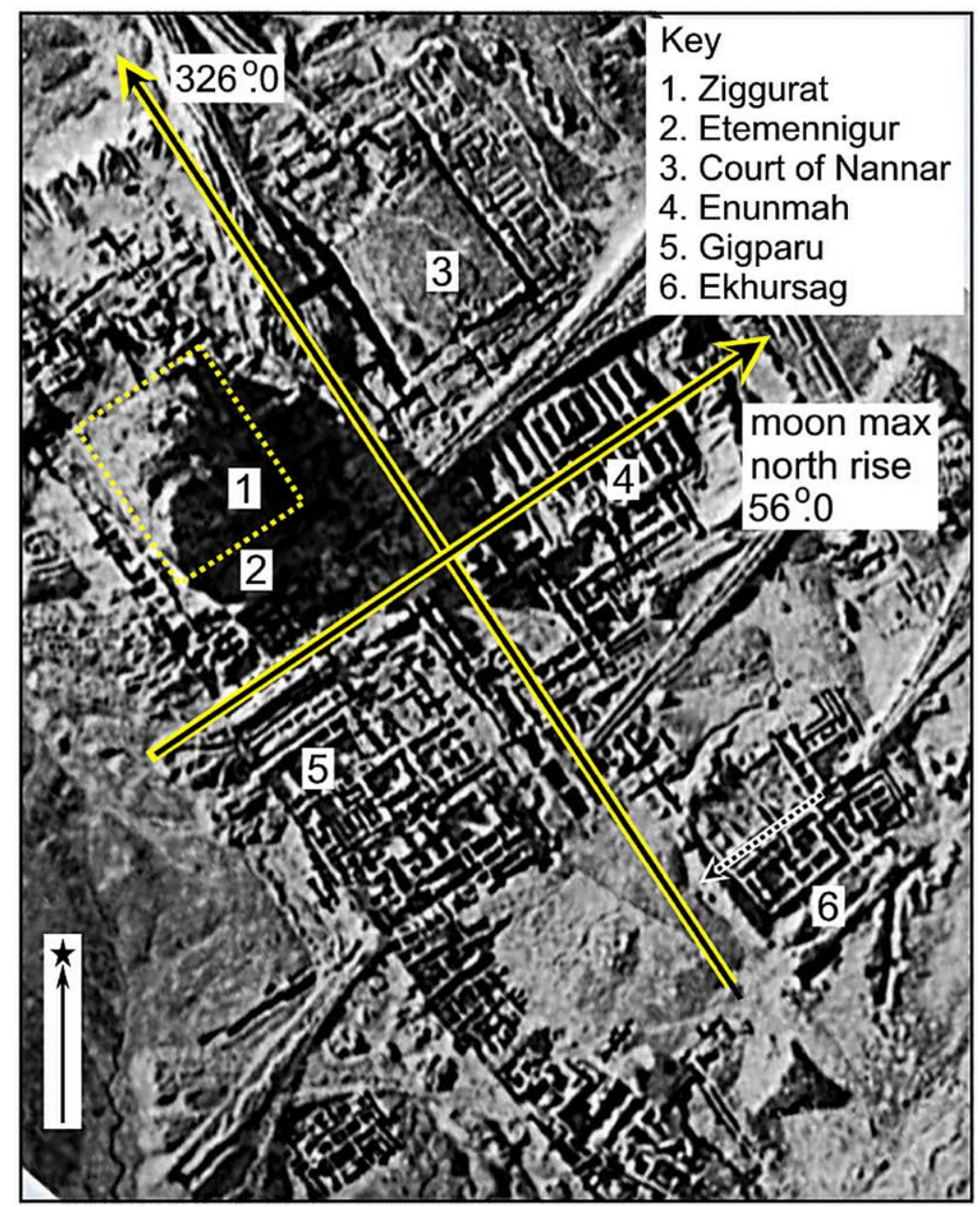

FIGURE 6. 1927 aerial photograph of Ur with lunar azimuths as shown. The controlling alignment is to the Moon's maximum north rise at $56.0^{\circ}$. The major axis of the city extends in an orthogonal fashion to the lunar azimuth (photograph by British Royal Air Force, from British Museum Quarterly 1, pl. XLIVa annotation by author). 


\section{The Great Ziggurat}

The Great Ziggurat (Figure 7) visually dominates the city of Ur. The three-stepped structure is about $61 \mathrm{~m} \times 46 \mathrm{~m}$ at its base, and $21 \mathrm{~m}$ in height. Initial construction was begun by Ur-Nammu (r. c. 2113-2096 BC), completed by his son, Shulgi, and rebuilt 1550 years later by King Nabonidus of Babylon. Saddam Hussein restored the ziggurat to its present appearance in the 1980s, rebuilding the lower brick facade and three massive stairways at the front.

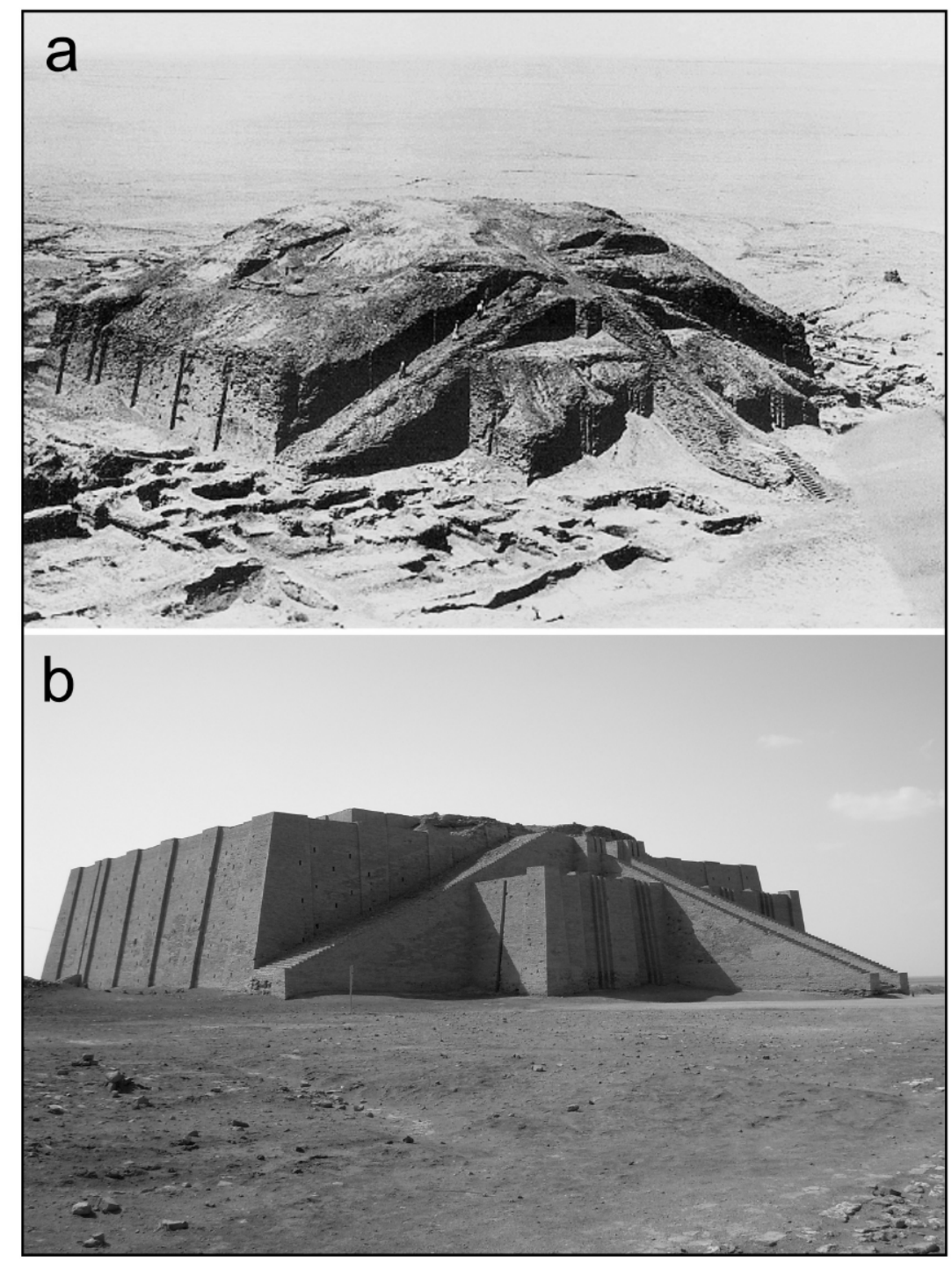

FIGURE 7. (a) Early aerial photo of the Great Ziggurat of Ur (from Woolley 1939, pl. 41); (b) photo of restored ziggurat c. 2012 (photo credit: Elena L. Pasquini - Creative Commons Attribution: Open Knowledge. Photo from: http://www.epistematic.com/2012/05/dhi-gar-university-and-heritage-project/ur-ziggurat/). 
Evidence that the ziggurat was built by King Ur-Nammu is provided by a tablet found during an excavation into the structure by J. E. Taylor in the 1850s. According to Woolley (1955a, 127): "Hidden in the brickwork of the top stage of the tower he [Taylor] found, at each angle of it, cylinders of baked clay on which were long inscriptions giving the history of the building. The texts date from about $550 \mathrm{BC}$, from the time of Nabonidus, [...] and state that the tower, founded by Ur-Nammu and his son Dungi [Shulgi], but left unfinished by them and not completed by any later king, he had restored and finished".

In truth, it seems unlikely that in his long reign, Shulgi did not complete construction of the ziggurat. Accounting for Nabonidus' comment, it may be that Nabonidus thought the ziggurat should have more than three stages and for that reason was incomplete. Indeed, it has been suggested that Nabonidus added several more stages (Woolley and Moorey 1982, 234).

Deep shadows in the ziggurat area of the 1927 aerial photo (Figure 6) preclude archaeoastronomic assessment of the ziggurat using that photo. The aerial photo from 1930 is better (although it shows slightly less detail). Figure 8a shows an enlarged detail of the 1930 photo. Using the Google Earth images of the Enunmah building walls and the same procedure as described above, the 1930 aerial photo was rotated and oriented to true north. Compared to the 1927 aerial photo, what distinguishes the 1930 photo is that it clearly shows the pre-restoration western edge of the ziggurat. As line A in Figure 8a shows, the azimuth for this edge is $326.0^{\circ}$, which means that the minor axis of the ziggurat is pointing directly to the lunar maximum north rise at $56.0^{\circ}$.

Figure $8 \mathrm{~b}$ shows a recent Google Earth image of the ziggurat. Comparison with the 1930 aerial photo indicates that modern restoration work did not materially affect the orientation of the structure. Moreover, as noted, ground survey of the centre stairway by Nadali and Polcaro (2016) confirms that the stairway extends along an azimuth of $56^{\circ}$ and, as they also suggest, is lunar aligned. Together, these data support the notion that the ziggurat was aligned to the Moon's maximum north rise. According to calculations by Nadali and Polcaro $(2016,107)$, a maximum north Moon rise occurred during the second year of Ur-Nammu's reign and again during the third year of Shulgi's reign.

\section{Etemennigur}

The Etemennigur was the sacred rectangular area surrounding the ziggurat comprised of a raised terrace surrounded by thick mud walls and having multiple chambers or rooms built in. Woolley (Woolley and Moorey 1982, 140) notes that when he observed them, the extant walls in the northwest part of the structure were still $5 \mathrm{ft} 6$ inches $(168 \mathrm{~cm})$ in height. Documentation that the Etemennigur was built by Ur-Nammu and dedicated to the Moon-god Nanna is provided by an inscription stamped on foundation cones set into the walls: "For Nanna the strong bull of Heaven, most glorious son of Enlil, his King, has Ur-Nammu the mighty man, King of Ur, built this temple, Etemennigur" (Woolley and Moorey 1982, 140). Figure 9a shows how the Etemennigur is oriented to the Moon's maximum north rise. 

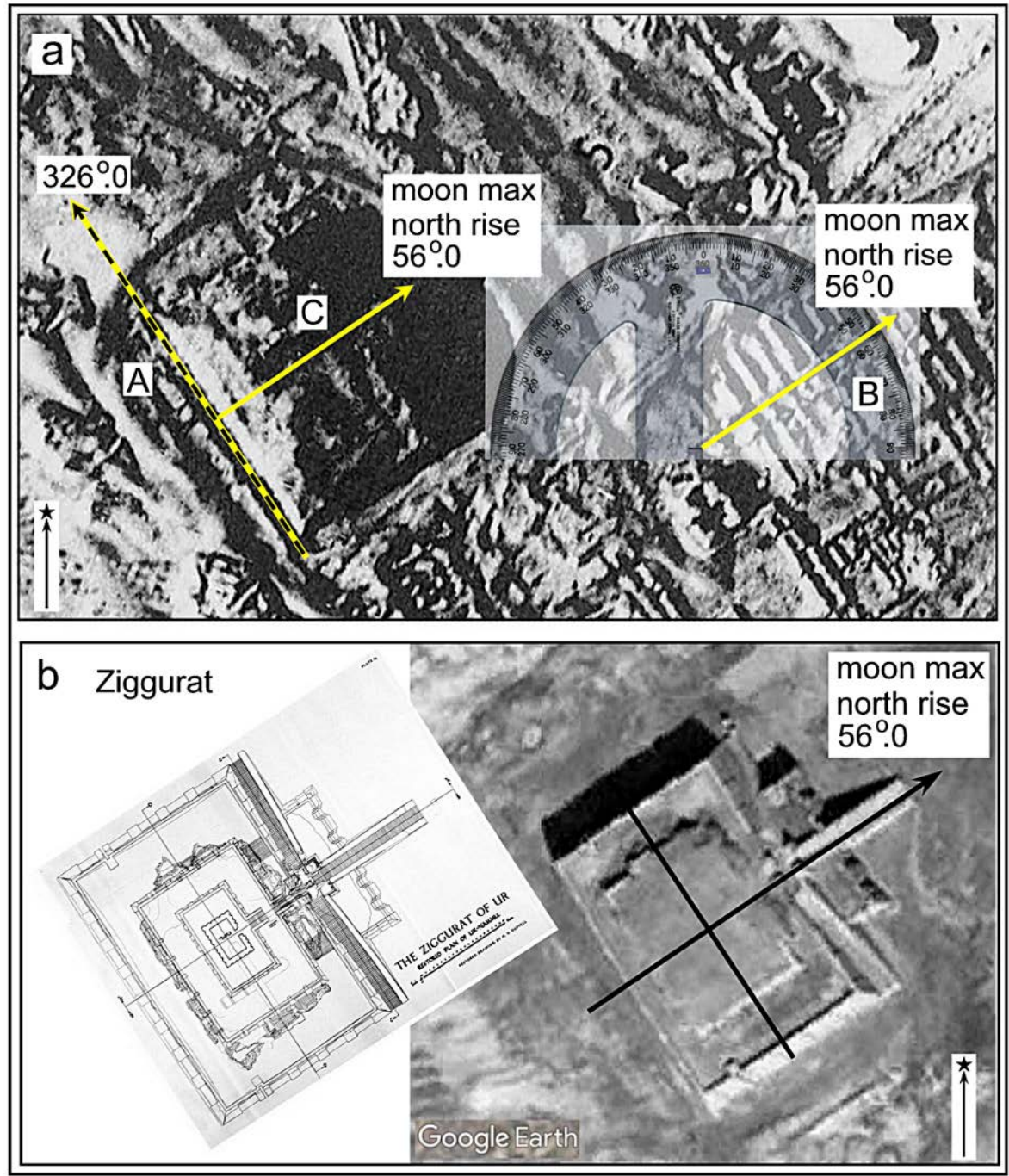

FIGURE 8. (a) Enlarged detail from 1930 aerial photo (photograph by British Royal Air Force, from British Museum Quarterly 1, pl. XLIVa - annotation by author, based on Woolley 1934, pl. 2); (b) left: plan of ziggurat (from Woolley 1939, pl. 84), right: Google Earth image of ziggurat (annotation by author).

\section{Giparu}

The Giparu was located to the immediate southeast of the ziggurat and Etemennigur enclosure. The Giparu was both a temple and residence. An inscription quoted by Woolley $(1955 a, 122)$ reveals that the structure was built by Ur-Nammu: "For Ningal his Lady Ur-Nammu the mighty man, King of Ur, King of Sumer and Akkad, has built her splendid Gigparu".

The manner in which buildings in general and the Giparu in particular were rebuilt following in the footprints of Ur III foundations is explained by Woolley $(1955 a, 166)$ : 
Ishmedagan's daughter Enannatum, High Priestess of Nanna, determined to rebuild it [the Giparu] on the old lines but in better material, using burnt brick throughout. Excavating the site, we found her building standing on the stumps of the older walls which had been used by the new bricklayers as a foundation, and so recovered at one time the ground-plan of both temples.

Figure 9b shows how the Giparu is oriented to the Moon's maximum north rise.

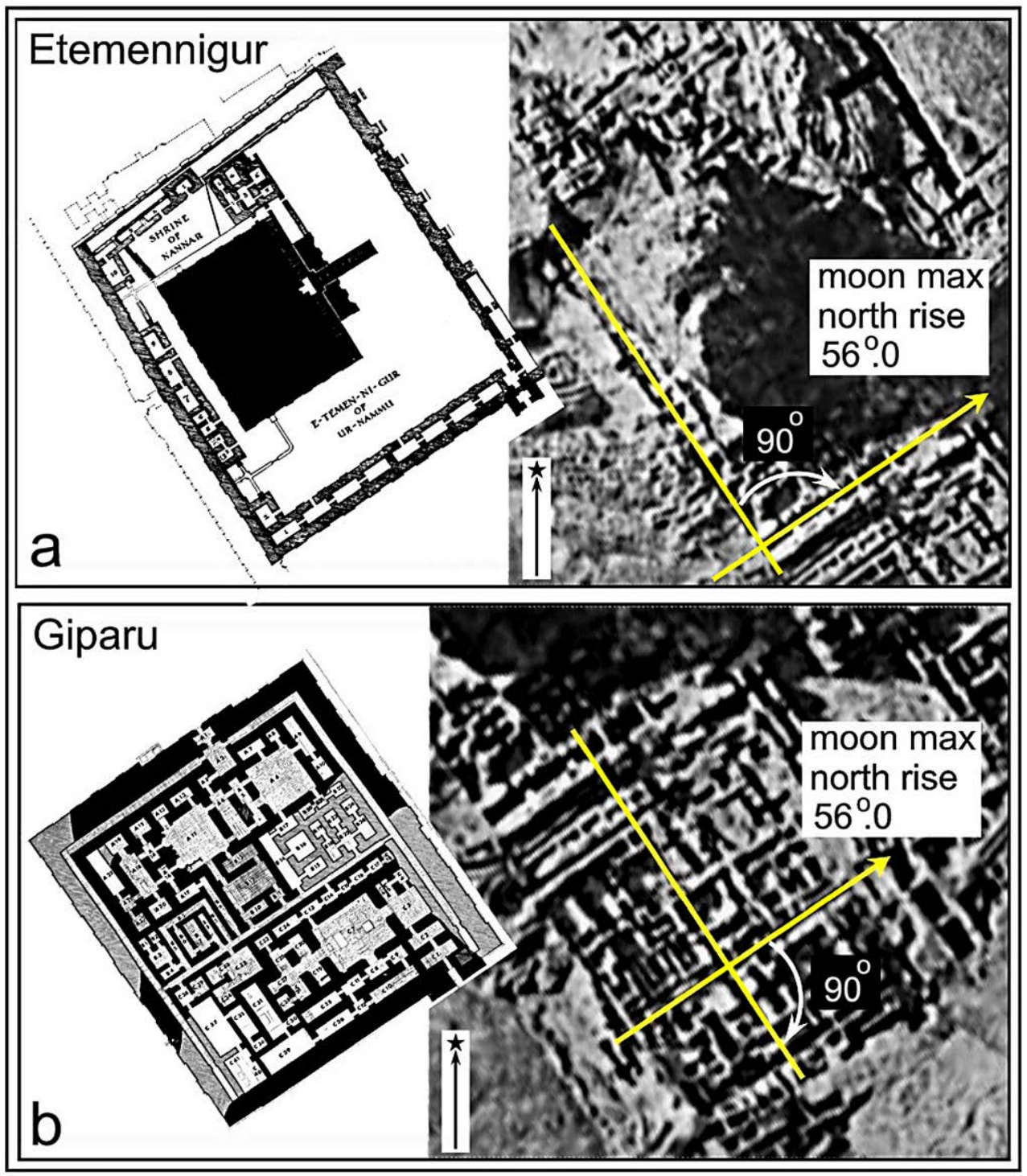

FIGURE 9. (a) Left: plan of Etemennigur (from Woolley 1939, pl. 68), right: enlarged and annotated detail from 1927 aerial photo (photograph by British Royal Air Force, from British Museum Quarterly 1, pl. XLIVa - annotation by author); (b) left: plan of Giparu (from Woolley 1974, pl. 53), right: enlarged and annotated detail from 1927 aerial photo. 


\section{The Court of Nanna}

The Court of Nanna is located northeast of the ziggurat and Etemennigur. It was a sunken courtyard surrounded by thick walls and like the Etemennigur, had multiple chambers, or rooms within its walls. Figure 10a shows how the Court of Nanna is oriented to the Moon's maximum north rise.

\section{Ekhursag}

Woolley $(1955 a, 147,150)$ notes there were two Ur III structures that were "undisturbed": the Royal Mausoleum and the Ekhursag building. As to the latter, he writes that (Woolley 1955a, 148) "Ur-Nammu founded the building and the bricks of the walls bear his stamp, but apparently he died before it was finished, for the pavement bricks bear the stamp of this son, Dungi [Shulgi]." Woolley's $(1955 a, 149)$ further opinion was that the Ekhursag building was "the palace of the Third Dynasty kings, the northwest part of it being the official Hall of Audience, the two residential blocks the living-quarters of the king and of his harem respectively".

What makes the Ekhursag building unique is that rather than being oriented to the Moon's maximum north rise, the structure is more closely oriented to the Moon's maximum south set (Figure 10b). The possible alignment, however, is not precise. The building orientation differs from the ideal south lunar maximum set azimuth by $1.9^{\circ}$.

As noted earlier and in the quote below, one of the roles of the Moon god was to act as a judge and administrator in the underworld. The Moon god fulfilled this role during the dark Moon phase when he disappeared into the netherworld. Notably, the Moon's maximum south set represents the Moon's lowest declination and therefore its furthest position south in the night sky - analogous, perhaps, to the lowest levels of the netherworld and the location for the Moon god in judgment mode.

Maybe alignment of the king's palace to the place where the Moon god resided as judge was intended as a reminder that the terrestrial king and divine Moon god had corresponding roles as judges - one in this world, the other in the netherworld.

\section{Voyage of the Moon God: The Journey of Nanna}

A favourite theme in Mesopotamian literature involves a journey by the protagonist to a distant land with various trials and adventures along the way. Examples include the story of Inanna's descent into the netherworld, Gilgamesh's search for immortality and Enki's journey to Nippur. Among the most famous of the epic journeys is the Journey of Nanna to Nippur (Kramer 1961 [1944], 47-49).

The Journey of Nanna story has been pieced together from thirty texts and fragments recovered mostly from Nippur but with one fragment from Ur (Ferrara 1973, 30). According to Ferrara $(1973,30)$, "The texts stem from the Old Babylonian period [2000-1600 BC], but the Vorlage probably goes back to the Neo-Sumerian period (c. 2140-2020 BC)" (Ferrara 1973). The story is of special importance because it accounts for the abundance of resources enjoyed by the people of Ur. The story also appears to encode astronomic information concerning the Moon. 


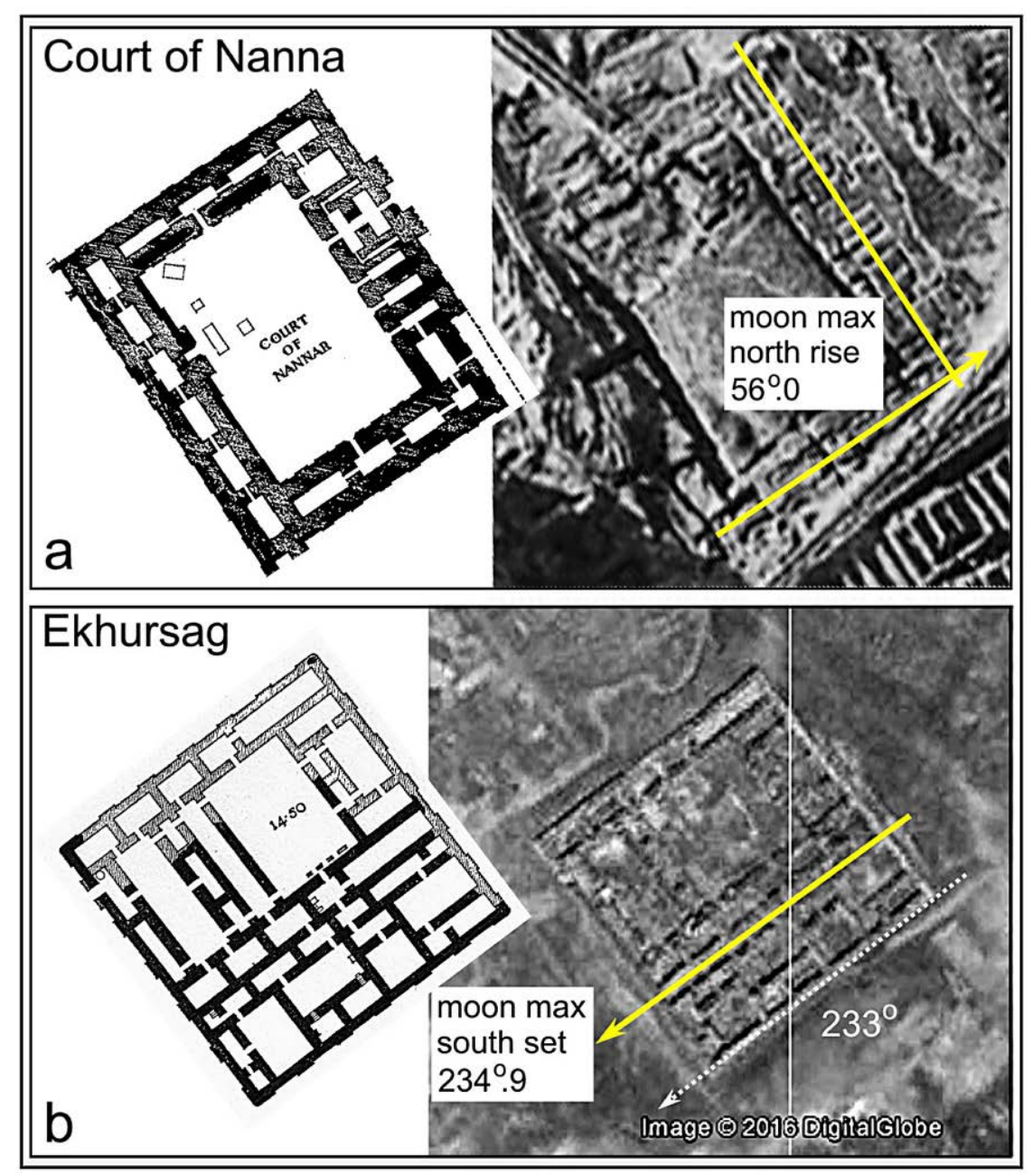

FIGURE 10. (a) Left: plan of Court of Nanna (from Woolley 1974, pl. 53), right: enlarged detail from 1927 aerial photo - curved dark shadows are dug trenches, not walls (photograph by British Royal Air Force, from British Museum Quarterly 1, pl. XLIVa - annotation by author); (b) left: plan of Ekhursag (from Woolley 1976, pl. 117), right: Google Earth image (annotation by author).

In the Journey of Nanna story, Enlil (god of wind and storms) lives in the city of Nippur; while Nanna, who is his son, lives in Ur. One day Nanna decides to visit his father and undertakes the journey to Nippur by boat up the Euphrates River. Nanna loads his boat with animals, trees and plants as gifts for his father. Upon arrival at Nippur, father and son sit down to a feast. At dinner Nanna comes to the point of his journey and asks a favour of his father (Black et al. 2004, 153 = lines 331-339):

Give to me Enlil, give to me [...]! In the river give me the carp-food [...]! In the fields give me speckled barley [...]! In the reed-beds give me old reed and fresh reed [...]! In the orchards give me syrup and wine [...]!. In the palace give me long life [...]. 
Enlil grants these wishes and Nanna returns to Ur. The story mirrors the request (Black et al. 2004, 153-154 = lines 340-348):

In the river he gave him the carp-flood [...]. In the field [sic for singular] he gave him speckled barley [...]. In the reedbeds he gave him old reed and fresh reed [...]. In the orchards he gave him syrup and wine -- and he set off for Urim. In the palace he gave him long life [...].

In this story it is Nanna, the Moon god, whom the people of Ur can thank for their abundance.

Of interest is that the Journey of Nanna names five cities along the Euphrates River or associated canals where Nanna stopped. Proceeding northward from Ur, and according to the order given in the original texts, these cities are Ennegi, Larsa, Uruk, Shuruppak and Tummal (Ferrara 1972, 26). Figure 11 shows the known locations for Larsa, Uruk and Shuruppak, and the less certain locations for Ennegi and Tummal. Ennigi is described as situated between Ur and Larsa, while Tummal is between Shuruppak and Nippur (Black et al. 2004, 150). At each city-stop the patron goddess for that city initially believes that Nanna is bringing offerings for her. But as explained in the following passages (Black et al. 2004, 150-151 = lines 209-252), this is not the case:

Larsa lay ahead of the offerings, Enegir [Ennegi] lay behind them. [...At Larsa] She [Sherida, goddess of light] laid out flour before the barge and spread bran. [...] But the boat did not give her its cargo: "I am going to Nibru [Nippur]!" [...] Unug [Uruk] lay ahead of the offerings, Larsa lay behind them. [...] Suruppag lay ahead of the offerings, Unug [Uruk] lay behind them. [...] Tummal lay ahead of the offering, Suruppag lay behind them. [...] Nibru [Nippur] lay ahead of the offerings, Tummal lay behind them.

The trajectories of the Euphrates and Tigris rivers as they existed thousands of years ago are difficult to trace with certainty, and opinions differ (e.g. Jacobsen 1960; Adams 1981; Steinkeller 2001; Pournelle 2003; Hritz 2010; Ur 2013; Jotheri 2016, Jotheri et al. 2017; Rey 2019). The problem is that because southern Mesopotamia is so flat, the Tigris and Euphrates have frequently changed course due to flooding and fluctuating sea levels, thereby creating new river channels and leaving a complex of relic signatures on the ground. Moreover, there are hundreds (maybe thousands) of ancient canals crisscrossing the area. As a result, it is difficult to establish precise trajectories for which waterways were active at any given time. (In the case of Tummal and Larsa those cities were apparently connected to the Euphrates River via canals - for example, the Shatt en-nil canal in the case of Larsa.)

The important point for the present discussion is that according to the story, Ur and Nippur were connected by waterways, and in his boat journey to Nippur Nanna could have stopped at any number of places along the way. In this case, however, the number of stops seems relevant. I believe the number references the number of months in a year - in Figure 12, the time and distance separating each city where Nanna stopped is one interval, and counting the number of intervals for Nanna's round-trip voyage, that number totals twelve. There were differences in Sumerian calendars among city-states 


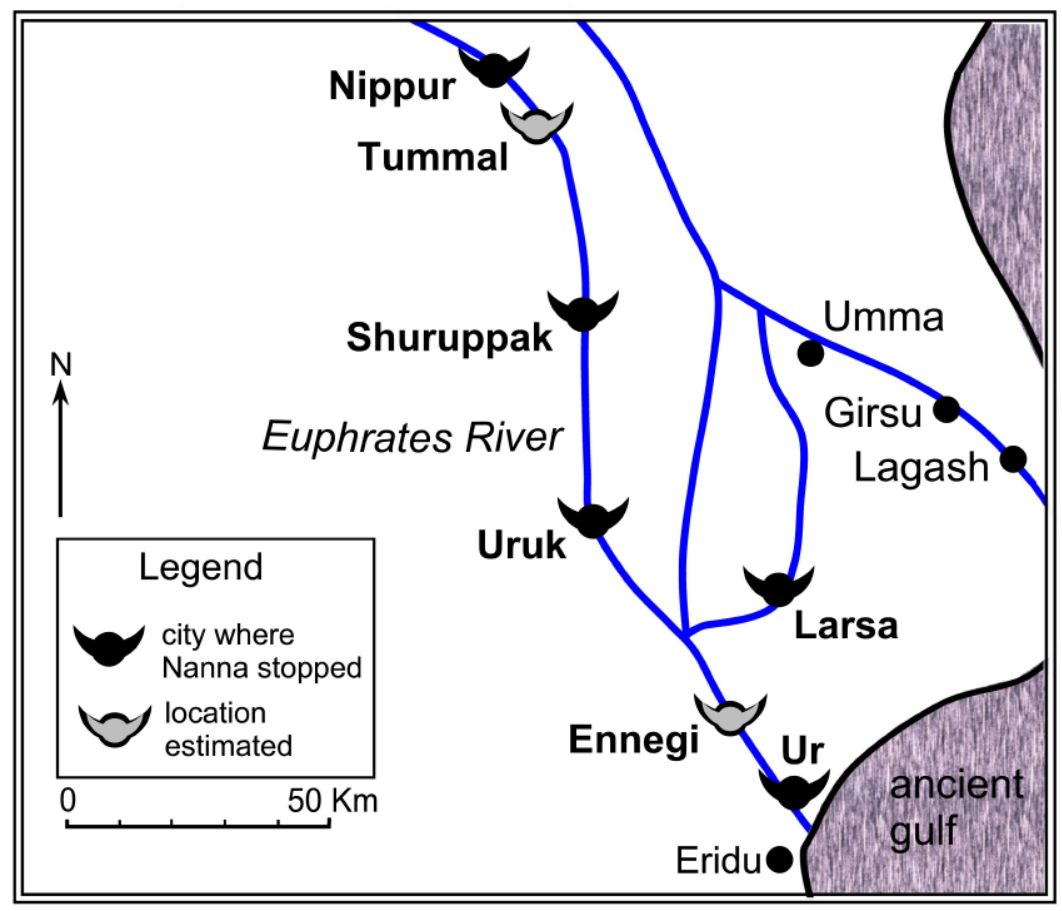

FIGURE 11. Schematic plan showing Nanna's stops between Ur and Nippur. Locations for Ennegi and Tummal estimated (drawing by author, base map after Rey 2019, fig. 1).

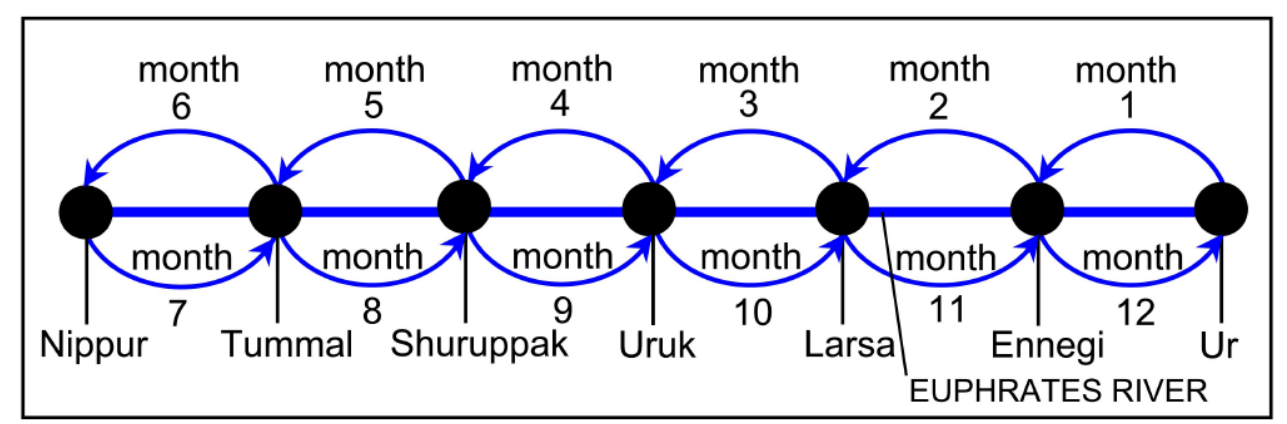

FIGURE 12. Schematic drawing showing how the city stops made by Nanna during his voyage along the Euphrates River corresponds to the number of lunar months in the year.

(Sharlach 2013, 311-315). Notably, however, division of the year into 12 months finds expression in the Ur III calendar, with the New Year beginning around the time of the spring equinox (Britton 2007, 115).

If Nanna departed Ur around the time of the spring equinox, he would have arrived at Nippur after six intervals, or six months later at the autumn equinox. Following the reverse course, he would have returned to Ur another six months later, at the spring 
equinox, bringing with him the blessings of Enlil. Of course, in real life a journey of a couple of hundred miles would have taken much less time than this - but this delay can be explained by Nanna having stopped at intervals along the way.

The annual spring akitu festival marked the return of the Moon god to Ur, and it was timed to correspond with the equinox (Cohen 1993, 140); Cohen describes Nanna's entry into the city by barge as the festival's "high point" (Cohen 1993, 142). The stops that Nanna made in his journey might be interpreted as metaphors for the Moon's monthly dark Moon phase (when the Moon is not visible in the night sky) - when Nanna disappears into the underworld to judge the dead. The following hymn to Nanna documents that monthly occurrence (Jacobsen 1976, 122):

When you have measured the days of a month

When you have reached this day,

[missing line]

When you have made manifest to the people, your "day of lying down" of a completed month, You grandly judge, o lord, law cases in the underworld, make decisions superbly....

According to Jacobsen $(1976,122)$, special offerings were made at Ur on dark Moon days.

Given the above, it seems possible that the story of Nanna's journey encodes within it the number of months in a year, as well as perhaps being an allegorical representation of the Moon's oscillation along the horizon from south to north and back again to south. The allegory is especially appropriate given that Nanna is sometimes shown standing in a silver boat presumably journeying across the night sky. As Figure 13 shows, the crescent phase of the Moon resembles a Sumerian skiff. And certainly the silver color is appropriate.

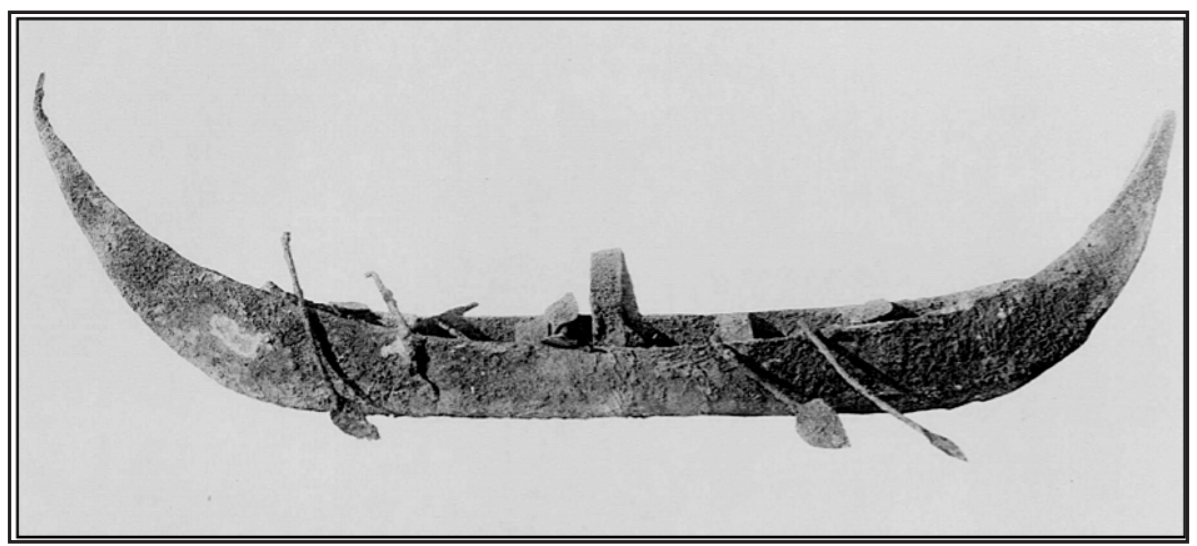

FIGURE 13. Silver boat model found in tomb of King Abargi, Royal Cemetery at Ur (from Woolley 1934, pl. 169).

As indicated above, the significance of Nippur as Nanna's destination is that Nippur was the city of Enlil, father of the Moon god. As explained by Kramer (1961 [1944], 47): 
"To the Sumerians of the third millennium BC, Nippur was the spiritual center of their country." Generations of Sumerian rulers journeyed to Nippur for their coronations and to pay homage to Enlil, including Ur-Nammu (Hallo 1966). Nippur was seen as being at the centre of the Sumerian cosmos, the place where the Earth (Ki) and Sky (An) had been separated by Enlil, ending their constant union causing the Earth to become pregnant with the other, lesser gods (George 2016, 6-7).

Nippur is located $154 \mathrm{~km}$ northwest of Ur, at $32^{\circ} 07^{\prime} 29^{\prime \prime} \mathrm{N}$ latitude $\times 45^{\circ} 13^{\prime} 46^{\prime \prime} \mathrm{E}$ longitude. As measured from Ur, the azimuth to Nippur is $327.4^{\circ}$. Of interest is that the major axis of Ur extends along an azimuth of $326.0^{\circ}$ (Figure 14). Thus, the longitudinal axis of Ur points to Nippur to within $1.0^{\circ}-1.5^{\circ}$ degrees. It is likely that this azimuth relationship is fortuitous, given that major Sumerian cities were typically built on the higher ground offered by Pleistocene-era "turtlebacks" (Pournelle 2013, 22). At the same time, however, Sumerians were experts in constructing long canals, thus implying some level of expertise about how to lay out long sightlines (perhaps using the equivalent of simple devices such as the droma or dioptra). They also made regular journeys for trading and conquest across vast stretches of territory, further indicating expertise in long-distance navigation. Accordingly, the possibility at least needs to be considered that the Sumerians recognised that the major axis of Ur points toward Nippur and that the azimuth connecting the two cities was very close to the orthogonal of the Moon's maximum north rise.

In this admittedly speculative scenario, perhaps the Moon's movement along the eastern horizon recalled the legendary relationship between Ur and Nippur. As the Moon made its journey in the night sky from south to north and back again it re-enacted the journey of Nanna from Ur to Nippur and back to Ur-reinforcing the understanding that the fortunes of Ur were directly tied to Nippur, the spiritual centre of the empire and cosmos.

\section{Shulgi's Run}

The other story that connects Ur and Nippur to the Moon is the story of King Shulgi's marathon run. The story tells how Shulgi (son of King Ur-Nammu) (Figure 15) ran from Nippur to Ur and back again in one day. His intention was to celebrate the eshesh feast (a lunar festival) in both cities on the same day. The round-trip distance is about 322 km. By any standard Shulgi's run was a remarkable achievement (Black et al. $307=$ lines 77-79):

[my] my saĝursaĝ priests looked at me with admiration. I celebrated the ešeš festival in both Nibru and Urim [i.e. Nippur and Ur] on the same day!

The logistics of Shulgi's claim have been examined and, while extraordinary, his feat is physiologically possible, with equivalent runs having been documented (Lamont 1995). Of interest in the present context is that the story again connects Ur and Nippur by way of the Moon (i.e., the lunar festival). And, another Sumerian name for the Moon god Nanna was as-im-babbar, "the lonely white runner" (Stol 1992, 245). 


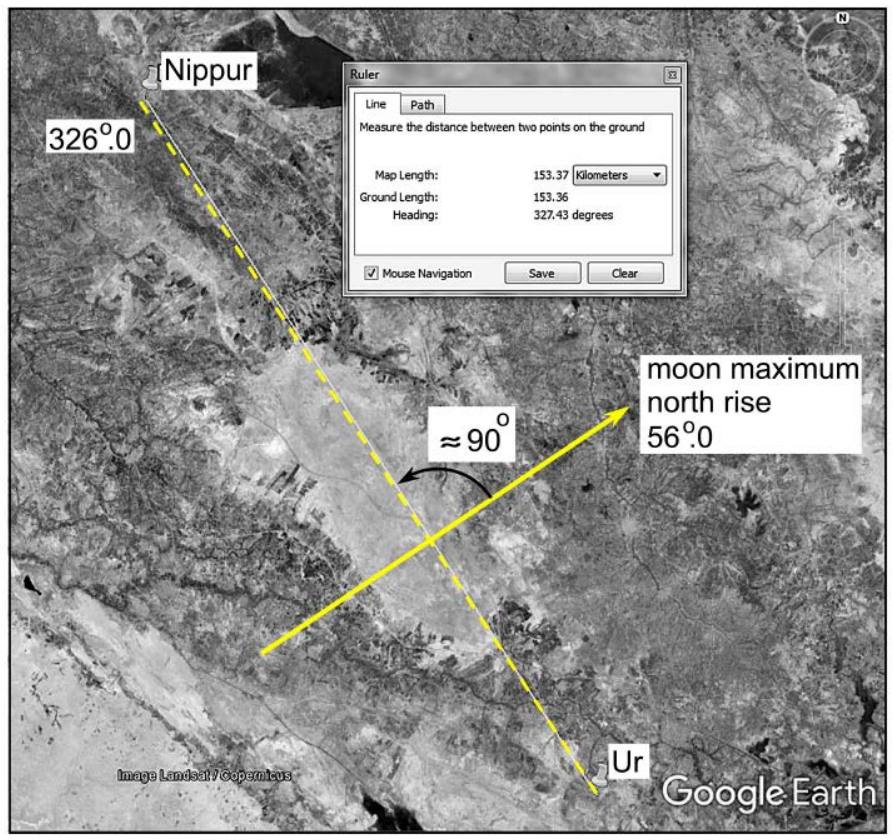

FIGURE 14. Google Earth image showing azimuthal relationship between Ur, Nippur and the Moon's maximum north rise. Thin white line = azimuth between Ur and Nippur; dashed yellow line $=$ orthogonal of Moon's maximum north rise (annotation by author).

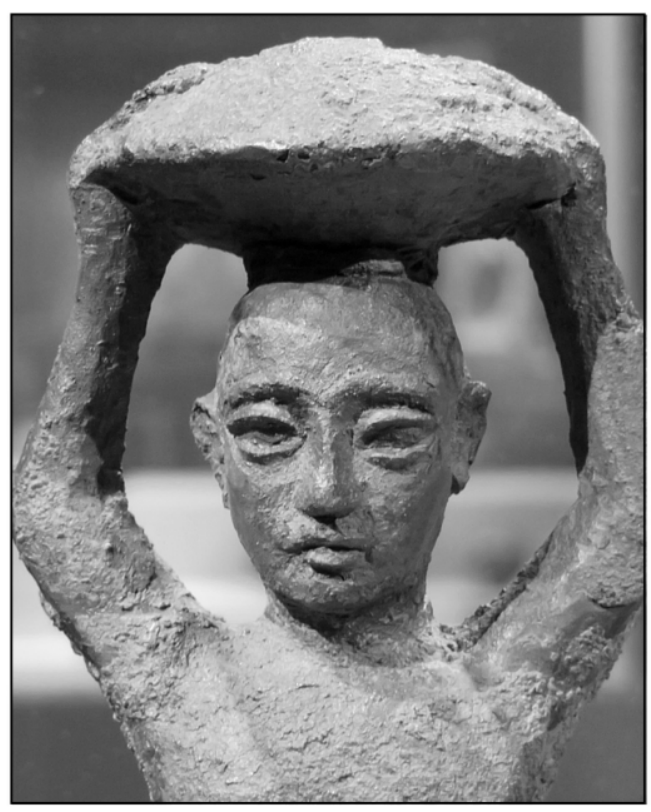

FIGURE 15. Detail of copper foundation pin showing King Shulgi. Here he is shown carrying a basket load of dirt used to make foundation bricks for construction of a temple at Nippur (on display at the Metropolitan Museum of Art, photograph by author). 


\section{Discussion}

We should forever dispense with the faulty argument that because lunar standstills happen infrequently - as in once in a generation - that posited alignments therefore must be fortuitous. While it is true, for example, that the maximum north or south lunar standstill occurs at a precise time and date once every 18.6 years, those events are easily anticipated many months in advance as the Moon slowly moves farther north and south each month. Depending on the limits of precision required by the viewer to declare a lunar maximum, multiple viewing opportunities occur for months preceding the exact dates. Using the computer planetarium program SkyMap Pro v.12 (Marriott 2016), for example, it is found that within two years of an exact date for the Moon's maximum or minimum extreme, the observer will see nearly a dozen Moon rises that are to within roughly $0.5^{\circ}$ of the exact standstill declination.

A related matter is the exact instant of a lunar extreme relative to the horizon. Of necessity, the exact maximum or minimum declination of the Moon during the course of a day will differ a bit from its declination at rise or set (for further discussion see Ruggles 1999, 49-67; González-García 2016; Fisher and Sims 2017, 206). The alignment at Ur to the Moon's north extreme is rather precise, however. From this it follows that either observers at Ur hit upon the exact lunar extreme north rise azimuth by chance, or, more likely, they tracked the Moon over a period of time before memorialising its rise with no discernible error.

That said, it is always important to ask whether any posited celestial alignment is intentional, or if it is in some way a function of local topography, or even entirely fortuitous. In Mesopotamia the Tigris and Euphrates rivers generally trend from northwest to southeast (Figures 1 and 11). The escarpment marking the boundary between Mesopotamia and the Arabian Desert also trends the same way, as do the Zagros Mountains to the east of Mesopotamia (Figure 1). Furthermore, at least today, the prevailing winds in central and southern Mesopotamia are generally out of the northwest (Hashim et al. 2013, fig. 1). For Ur, the issue is whether any of these phenomena controlled alignment of the city.

The Zagros Mountains and Arabian Desert escarpment are both far distant from Ur and so, as a practical matter, are probably not likely to have been used to orient Ur. On the other hand, cross-culturally, many prehistoric sites face a nearby river, so one might think that Ur could be aligned to the nearby Euphrates River. As a result of periodic flooding, however, the Euphrates (and Tigris) rivers often change direction, creating new channels along different azimuths. Indeed, although the Euphrates generally tracks from northwest to southeast, at a smaller scale the river meanders across the Mesopotamian plain. As a consequence, any proposed alignment with the river would have been fleeting at best.

Looking in more detail at Ur, assessment of Woolley's (1974, pl. 61) map (shown above as Figure 1) shows that the outside city walls are curved. The map reveals that the Euphrates River coursed along the city walls, as indicated by the positioning of the west harbour entrance through the northwest section of the city wall. And, with reference to the south section of city wall. Woolley $(1974,61)$ states that "[t]he river Euphrates ran against the SW side". 
Clearly, then, the Euphrates curved along the west city wall; and neither the river nor the wall were straight. From this, and as shown by the relevant maps (Woolley 1974, pls. $60,61)$, it is apparent that the river was not oriented in the same direction as the ziggurat, or major axis of the city. In other words, the city was not oriented with any specificity to the Euphrates River.

As regards the wind, there may well have been an intention to blade Ur, and other Mesopotamian cities along a northwest-southeast axis. Cursory review of Heinrich (1982), for example, shows the orientation of many Mesopotamian structures oriented along that trajectory. As a practical matter, such a blading would have mitigated the effects of damaging winds on reed-and-mud brick structures. In Mesopotamia, severe wind and dust storms are an ever-present danger; dust storms known as shamals come out of the north and northwest, whereas shargi wind storms come out of the south and southeast (Sissakian et al. 2013, 1085). The blading of buildings into the wind during ancient times is known for other desert environments (e.g., Rossi and Magli 2019). Like Mesopotamian rivers, however, the winds have a variable range rather than a set azimuth (Hashim et al. 2013, fig. 1). Accordingly, while there was likely a general preference to blade buildings into the wind and also more or less near and facing a river, at Ur the orientation of the ziggurat and city were apparently fine-tuned to the Moon, albeit within the ranges of wind and river. It is not unreasonable to think that Ur and other sites might have been simultaneously aligned generally and specifically to multiple phenomena. The options are not binary.

\section{Concluding Remarks}

In this article, multiple lines of evidence have been provided indicating that Ur was intentionally aligned to the Moon. Prima facie evidence comprised of aerial photographs showing how the city is lunar aligned was offered. Further, inscriptions on foundation cones document lunar associations and dedications, and new interpretations of two Sumerian stories reveal probable lunar data. Further support for the intentionality of the lunar alignments at Ur are the findings of celestial alignments at other Mesopotamian sites. Tiede $(2011,2018)$ and Nadali and Polcaro $(2016)$ have documented several celestial aligned ziggurats, including those at Asur, Chogha Zanbil, Marduk and Larsa. Thus Ur is not alone in its alignment to the heavens.

At Ur, entanglements with the Moon were made through physical alignments of the entire city as well as through ritual journeys and lunar festivals. If engagement with the Moon as a patron deity was the objective, then perhaps the hope was for abundance and long life - as gifted in legendary times and memorialised in the Journey of Nanna to Nippur story.

The rationale for the alignment of the city and ziggurat to the Moon's northernmost extreme is lost to time. It is worth noting, however, that when the Moon is at its most northerly declinations, it is also at its maximum vertical angle relative to a ground observer. Arguably, the higher the Moon's altitude (or elevation), the greater its dominion over the night sky. For the observer on the ground, the greater the Moon's strength and virility, the greater its influence is over earthly matters such as plant and 
animal abundance. For a city and its rulers who wished to associate themselves with the strength and beneficence of the Moon, the most auspicious time to make that connection would have been at the Moon's maximum north extreme, when it was at its maximum height.

Support for this interpretation is found in the observation that subsequent to King Shulgi, the next three Sumerian kings incorporated the Akkadian name for the Moon god into their personal names: Amar-Sin, Shu-Sin and Ibbi-Sin. In Sumer, names held power (Wolkstein 1983, 139), and for these kings, the power of the Moon was invoked by including the name for the Moon in their names. Who could oppose or deny that sort of legitimacy?

\section{Acknowledgements}

Special thanks to Alessandro Pezzati and the Penn Museum for permission to reproduce multiple illustrations from C. Leonard Woolley's volumes. Thank you also to Jaafar Jotheri for answering my questions about the course of Euphrates River. Sincere thanks to Liz Henty, Fabio Silva and Richard Bartholomew for editorial advice. And thank you to the anonymous reviewers for their comments. I am solely responsible, however, for any mistakes.

\section{References}

Adams, R. M., 1981. Heartland of Cities: Surveys of Ancient Settlement and Land Use on the Central Floodplain of the Euphrates. Chicago: University of Chicago Press.

Aveni, A. F., 2001. Skywatchers: A Revised and Updated Version of Skywatchers of Ancient Mexico. Austin: University of Texas Press.

Black, J., G. Cunningham, E. Robson and G. Zólyomi, 2004. The Literature of Ancient Sumer. Oxford: Oxford University Press.

Black, J. and A. Green, 1992. Gods, Demons and Symbols of Ancient Mesopotamia. Austin: University of Texas Press.

Britton, J. P., 2007. "Calendars, Intercalations and Year-Lengths in Mesopotamian Astronomy". In Calendars and Years: Astronomy and Time in the Ancient Near East, edited by J. M. Steele, 115-132. Oxford: Oxbow Books.

Cohen, M. E., 1993. The Cultic Calendars of the Ancient Near East. Bethesda, MD: CDL Press.

Colbow, G., 1997. "More Insights into Representations of the Moon God in the Third and Second Millennium BC". In Sumerian Gods and Their Representations, edited by I. L. Finkel and M. J. Geller, 19-31. Groningen: Styx Publications.

Collon, D., 1992. "The Near Eastern Moon God". In Natural Phenomena: Their Meaning, Depiction and Description in the Ancient Near East, edited by D. J. W. Meijer, 19-37. Amsterdam: Royal Netherlands Academy of Arts and Sciences.

Ferrara, A. J., 1972. "The Itinerary of Nanna-Suen's Journey to Nippur". Orientalia (new series) 41 (1): 1-4.

Ferrara, A. J., 1973. Nanna-Suen's Journey to Nippur. Rome: Biblical Institute Press.

Fisher, D. and L. Sims, 2017. "Modelling Lunar Extremes". Journal of Skyscape Archaeology 3 (2): 207-216. https://doi.org/10.1558/jsa.34686

George, A. R. 2016. "Die Kosmogonie des alten Mesopotamien". In Anfang \& Ende: vormoderne Szenarien von Weltentstehung und Weltuntergang, edited by M. Gindhart and T. Pommerening, 7-25, 132-133, 140. Darmstadt: von Zabern.

González-García, A. C., 2015. "Lunar Alignments - Identification and Analysis". In Handbook of Archaeo- 
astronomy and Ethnoastronomy, edited by C. L. N. Ruggles, 493-506. New York: Springer. https://doi. org/10.1007/978-1-4614-6141-8 37

González-García, A. C., 2016. "Lunar Extremes, Lunar Cycles and the Minor Standstill". Journal of Skyscape Archaeology 2 (1): 77-84. https://doi.org/10.1558/jsa.v2i1.30035

Hallo, W. W., 1966. "The Coronation of Ur-Nammu". Journal of Cuneiform Studies 20 (3-4): 133-141. https:// doi.org/10.2307/1359648

Hashim, B. M., R. Ajmi and S. A. Abduljabbar, 2013. "Identification of Dust Sources in Iraq Using Meteorological Surface Data and Satellite Data". Journal of Environmental Science and Engineering A2: 299-305.

Heinrich, E., 1982. Die Tempel und Heiligtumer im alten Mesopotamien: Typologie, Morphologie und Geschichte, 2 vols. Berlin: Verlag Walter de Gruyter.

Hritz, C., 2010. "Tracing Settlement Patterns and Channel Systems in Southern Mesopotamia Using Remote Sensing". Journal of Field Archaeology 35 (2): 184-203. https://doi.org/10.1179/009346910X127073215 20477

Jacobsen, T., 1960. "The Waters of Ur". Iraq 22: 174-185. https://doi.org/10.2307/4199683

Jacobsen, T., 1976. The Treasures of Darkness: A History of Mesopotamian Religion. New Haven, CT: Yale University Press.

Jotheri, J., 2016. Holocene Avulsion History of the Euphrates and Tigris Rivers in the Mesopotamian Floodplain. Phd diss., Durham University, Durham.

Jotheri, J., M. Altaweel, A. Tuji, R. Anma, B. Pennington, S. Rost and C. Watanabe, 2017. “Holocene Fluvial and Anthropogenic Processes in the Region of Uruk in Southern Mesopotamia". Quaternary International 483: 57-69. https://doi.org/10.1016/j.quaint.2017.11.037

Kosowsky, M., 2012. HeyWhatsThat [online]. Accessed October 2019, http://www.heywhatsthat.com/

Kramer, S. N., 1956. History Begins at Sumer: Thirty-Nine Firsts in Recorded History. Philadelphia: University of Pennsylvania Press.

Kramer, S. N., 1961 [1944]. Sumerian Mythology: A Study of Spiritual and Literary Achievement in the Third Millennium BC. Philadelphia: University of Pennsylvania Press.

Lamont, D. A., 1995. "Running Phenomena in Ancient Sumer". Journal of Sport History 22 (3): 207-215.

Leick, G., 1991. A Dictionary of Ancient Near Eastern Mythology. London: Routledge.

Marriott, C. A., 2016. Sky Map Pro (version 12) [online]. Accessed October 2019, http://www.skymap.com/

McCormac, J. C., 1991. Surveying Fundamentals (2nd edition). Englewood Cliffs, NJ: Prentice Hall.

Nadali, D. and A. Polcaro, 2016. “The Sky from the High Terrace: Study on the Orientation of the Ziggurat in Ancient Mesopotamia". Mediterranean Archaeology and Archaeometry 16 (4): 103-108.

National Oceanic and Atmospheric Administration, n.d. "Magnetic Field Calculators" [online]. Accessed October 2019, https://www.ngdc.noaa.gov/geomag/calculators/magcalc.shtml

Potere, D., 2008. "Horizontal Positional Accuracy of Google Earth's High Resolution Imagery Archive". Sensors 8 (12): 7973-7981. https://doi.org/10.3390/s8127973

Pournelle, J. R., 2003. Marshland of Cities: Deltaic Landscapes and the Evolution of Early Mesopotamian Civilization. PhD diss., University of California, San Diego.

Pournelle, J. R., 2013. "Physical Geography". In The Sumerian World, edited by H. Crawford, 13-32. London: Routledge.

Pulighe, G., V. Baiocchi, and F. Lupia, 2015. "Horizontal Accuracy Assessment of Very High Resolution Google Earth Images in the City of Rome, Italy". International Journal of Digital Earth 9 (4): 342-362. https://doi .org/10.1080/17538947.2015.1031716

Rey, S., 2019. "Girsu: Home of the Thunderbird". World Archaeology 8 (11): 30-35.

Romain, W. F., 2017. "The Archaeoastronomy and Feng Shui of Xanadu: Kublai Khan's Imperial Mongolian Capital". Time and Mind 10 (2): 145-174. https://doi.org/10.1080/1751696X.2017.1310567

Romain, W. F., 2018a. "Ancient Skywatchers of the Eastern Woodlands". In Archaeology and Ancient Religion in the American Midcontinent, edited by B. H. Koldehoff and T. R. Pauketat, 304-341. Tuscaloosa: University of Alabama Press.

Romain, W. F., 2018b. "Supplemental Material for 'Solstice Alignments at Angkor Wat: Connecting to the Cycles of Time'". Journal of Skyscape Archaeology 4 (2): S1-S17. https://doi.org/10.1558/jsa.38250 
Rossi, C. and G. Magli, 2019. "Wind, Sand and Water. The Orientation of Late Roman Forts in the Kharga Oasis (Egyptian Western Desert)". In Archaeoastronomy in the Roman World, edited by G. Magli, A. C. GonzálezGarcía, J. Belmonte Aviles and E. Antonello, 153-166. Cham, Switzerland: Springer. https://doi.org/10.10 07/978-3-319-97007-3_10

Ruggles, C., 1999. Astronomy in Prehistoric Britain and Ireland. New Haven, CT: Yale University Press.

Saggs, H. W. F., 1988. The Babylonians: A Survey of the Ancient Civilization of the Tigris-Euphrates Valley. London: Folio Society.

Sharlach, T., 2013. "Calendars and Counting". In The Sumerian World, edited by H. Crawford, 305-318. London: Routledge.

Sissakian, V. K., N. Al-Ansari and S. Knutsson, 2013. "Sand and Dust Storm Events in Iraq". Natural Science 5 (10): 1084-1094. https://doi.org/10.4236/ns.2013.510133

Sparavigna, A. C., 2016. "A Ziggurat and the Moon". PHILICA Art. 618 [online]. Accessed July 2018, https:// www.ssrn.com/abstract $=2797629$

Steinkeller, P., 2001. "New Light on the Hydrology and Topography of Southern Babylonia in the Third Millennium". Zeitschrift für Assyriologie und Vorderasiatische Archäologie 91 (1): 22-84. https://doi.org/10.15 15/zava.2001.91.1.22

Stol, M., 1992. "The Moon God as Seen by the Babylonians". In Natural Phenomena: Their Meaning, Depiction and Description in the Ancient Near East, edited by D. J. W. Meijer, 245-277. Amsterdam: Royal Netherlands Academy of Arts and Sciences.

Tiede, V., 2011. "Ziggurat, Khirigsuur \& Ling: Ancient Astro-Architecture Across Asia". Paper presented at the 19th Annual Meeting of the European Society for Astronomy in Culture (SEAC XIX), Évora, Portugal, 5th-9th September.

Tiede, V., 2018. "Ziggurats of Mesopotamia: An Astro-Archaeological Analysis". Paper presented at the 26th Annual Meeting of the European Society for Astronomy in Culture (SEAC XXVI), Graz, Austria, 28th August-1st September.

Ur, J., 2013. "Patterns of Settlement in Sumer and Akkad". In The Sumerian World, edited by H. Crawford, 131-155. London: Routledge.

Wolkstein, D., 1983. "Interpretation of Inanna's Stories and Hymns". In Inanna: Queen of Heaven and Earth: Her Stories and Hymns from Sumer, edited by D. Wolkstein and S. N. Kramer, 136-173. New York: Harper \& Row.

Woolley, C. L., 1934. Ur Excavations, vol. 2: Plates. The Royal Cemetery. A Report on the Predynastic and Sargonid Graves Excavated Between 1926 and 1931 [Oxford]: Trustees of the British Museum and of the Museum of the University of Pennsylvania.

Woolley, C. L., 1939. Ur Excavations, vol. 5: The Ziggurat and Its Surroundings. [Oxford]: Trustees of the British Museum and of the Museum of the University of Pennsylvania.

Woolley, C. L., 1955a. Excavations at Ur: A Record of Twelve Years' Work. (3rd [corrected] impression) London: Ernest Benn.

Woolley, C. L., 1955b. Ur Excavations, vol. 4: The Early Periods. Philadelphia: Trustees of the British Museum and of the Museum of the University of Pennsylvania.

Woolley, C. L., 1965. The Sumerians. New York: W.W. Norton.

Woolley, C. L., 1974. Ur Excavations, vol. 6: The Buildings of the Third Dynasty. Philadelphia: Trustees of the British Museum and of the Museum of the University of Pennsylvania.

Woolley, C. L. 1976. Ur Excavations, vol. 7: The Old Babylonian Period. Philadelphia: Trustees of the British Museum and of the Museum of the University of Pennsylvania.

Woolley, C. L. and P. R. S. Moorey, 1982. Ur'of the Chaldees': A Revised and Updated Edition of Sir Leonard Woolley's Excavations at Ur by P. R. S. Moorey. Ithaca, NY: Cornell University Press.

Zettler, R. L. 1998. "Early Dynastic Mesopotamia". In Treasures from the Royal Tombs of Ur, edited by R. L. Zettler and L. Horne, 1-7. Philadelphia: University of Pennsylvania Museum of Archaeology and Anthropology.

Zettler, R. L. and L. Horne, eds, 1998. Treasures from the Royal Tombs of Ur. Philadelphia: University of Pennsylvania Museum of Archaeology and Anthropology. 